\title{
The Impact of Oral Health Practice and Oral Health Knowledge Level of Caregivers on Periodontal Status of Some Special Needs Adults in Aseer Region, Saudi Arabia
}

\author{
Mohammed MA. Abdullah Al-Abdaly ${ }^{1 *}$, Redwan Abdullah AbuEshy Almalki², \\ Ahmed Mohammed Ali Shalan ${ }^{3}$ \\ ${ }^{1}$ Periodontics and Community Dental Sciences Department, College of Dentistry, King Khalid University, Abha, Saudi Arabia \\ ${ }^{2}$ College of Dentistry, King Khalid University, Abha, Saudi Arabia \\ ${ }^{3}$ Armed Forces Hospitals, Southern Region, Khamis Mushait, Saudi Arabia \\ Email: *malabdaly20@gmail.com
}

How to cite this paper: Al-Abdaly, M.M.A.A., Almalki, R.A.A. and Shalan, A.M.A. (2019) The Impact of Oral Health Practice and Oral Health Knowledge Level of Caregivers on Periodontal Status of Some Special Needs Adults in Aseer Region, Saudi Arabia. Open Journal of Stomatology, 9, 108-124.

https://doi.org/10.4236/ojst.2019.95012

Received: March 21, 2019

Accepted: May 12, 2019

Published: May 15, 2019

Copyright $\odot 2019$ by author(s) and Scientific Research Publishing Inc. This work is licensed under the Creative Commons Attribution International License (CC BY 4.0).

http://creativecommons.org/licenses/by/4.0/

\begin{abstract}
Background: The objective of the present study is to evaluate the impact of oral health practice and knowledge level of caregivers on periodontal status of adults special needs in Aseer Region, Saudi Arabia. Methodology: A cross-sectional study was conducted on 180 caregivers and 180 adults with special needs divided into three equal groups $(\mathrm{n}=60+60+60)$ based on type of disabilities: Visual impairment group (I); moderate mental retardation group (II); and physical impairment group (III). Questionnaire forms were used to assess the oral health practice and knowledge level of caregivers. The clinical examination of special needs adults was done to assess the effect of oral health practice and knowledge level of caregivers on periodontal status of adults special needs. All data were collected and analyzed by the SPSS statistical software and (ANOVA) to assess the variations in the mean and standard deviation $( \pm$ SD) of clinical findings. Results: Acceptable periodontal, oral health knowledge, awareness and oral health practice were detected among caregivers, particularly, group (II) more than group (III) and group (I). But there were no significant differences in periodontal clinical parameter scores in the comparison between the study groups. Conclusion: It is concluded that the level of oral health practice and knowledge of caregivers included within the current study, were not effective in keeping periodontal health of special needs adults.
\end{abstract}

\section{Keywords}

Caregivers, Periodontal Knowledge, Special Needs Adults 


\section{Introduction}

The health of the community is connected with the physical, mental and social health of an individual [1]. Additionally, oral health is a complementary portion of public health and the health of the oral tissues [2] [3]. Consequently, the advancing of periodontal disease is clear evidence for the decline of knowledge and awareness of oral health [4].

A disability is a lack of the normal ability and activity of the special needs individuals that compose a fundamental part of the community. It is predestined that there are about 500 million disabled in the world [5] [6]. The proportion of special needs patients who moved to adulthood stage is growing, due to the evolution of pediatric and newborn care [7].

In Saudi Arabia, disability is a considerable economic and social problem. According to 2000 demographic survey, it was revealed that 135,000 Saudi people are disability individuals [8]. Recently, Saudi Arabia has evolved in the economy with the improvement of special needs patient medical care [9] [10]. Many researchers revealed that poor oral hygiene and the pathological changes in periodontal tissues among special needs individuals are more than normal individuals [11]. The periodontal status in special needs patients is usually correlating with different factors such as the patients' age, disability type, socioeconomic status and dental care available [12].

Recently, the increasing in the consciousness of this group special needs from the dental side due to their physical inability to have appropriate oral hygiene, moreover, difficulties in getting enough dental care in the dental office were noticed [13] [14] [15], especially in severe impairments that need caregivers, parents or siblings for keeping of good oral health. But there is a shortage in the knowledge of oral health among caregivers. They also do not have appropriate oral hygiene practice [16]. Many of these less lucky individuals can't cope with the specific health needs [17].

On the other hand, there is an increase in the incidence of dental diseases among special needs individuals in the Gulf Area. Therefore, the evaluation of caregivers behavior toward periodontal and oral health is necessary due to its impact on periodontal and oral health keeping among these kinds of individuals [18] [19]. Most studies in Saudi Arabia conducted on the effect of oral health knowledge on the periodontal status among normal patients and few studies were on special needs patients.

Furthermore, there was no study focused on the oral health practice and oral health knowledge level of caregivers and its effect on periodontal status among special needs adults in Aseer Region. Therefore, the aim of the study was to evaluate the impact of oral health practice and knowledge level of caregivers on the periodontal status among special needs adults in Aseer Region Saudi Arabia. At the end of the current study, the results that were obtained may help caregivers to maintain the health of periodontal tissues, among these patients in special needs centers in Saudi Arabia. 


\section{Material \& Methods}

\subsection{Study Design and Patient Selection}

The current cross-sectional study was carried out on 180 special needs patients and on 180 caregivers who visited the Outpatients' Dental Clinics, College of Dentistry at King Khalid University in the period between January 2018 and January 2019. Special needs individuals were divided into three equal groups ( $\mathrm{n}$ $=60+60+60$ ), visual impairment group (I), moderate mental retardation group (II) and physical impairment group (III).

All participants in the current study (special needs individuals and caregivers) were males. The standard of the inclusion of the present study was their close working with the special needs individuals. It is difficult to assess the level of oral health practice and oral health knowledge of all special need individuals' caregivers in Aseer region, Saudi Arabia. And also to evaluate its impact on the periodontal status of special also need individuals. Consequently, the sample in the current study depended on a selection of participating individuals who came to the Outpatients' Dental Clinics, college of dentistry, King Khalid University in Abha city of Aseer region. In such way that they represent the caregivers and their special need individuals in Aseer region possible.

The Scientific Research Committee, College of Dentistry, King Khalid University reviewed and approved the proposal of the study and the ethical clearance certificate was obtained (SRC/ETH/2018-19/081). The consent for participants was obtained before starting the study. All ethical steps of this study design were applied according to the Ethical Standards of the Helsinki Statement 1975 reviewed in 2008.

\subsection{Collection of Data and Clinical Examination}

A questionnaire for the present study was designed for an interview of all the caregivers' participants to assess the oral health practice and knowledge level of caregivers. The questionnaire was prepared in different languages due to the fact that was foreigners. The questionnaire was comprised of caregivers' personal, general and occupational information. Moreover, two portions of information. Part (I): Questions about the caregivers' periodontal, oral health knowledge and awareness. Part II: Questions about the caregivers' periodontal and oral health practice (Figure 1 and Figure 2).

The clinical examination of the assessment periodontal tissues as well as the oral hygiene status among special needs individuals was conducted by the authors as a second clinical step in the present study. Periodontal and oral health status of all the special needs individuals in the present study was evaluated by the assessment of; Plaque Index (PLI) [20], Gingival Index (GI) [21], Periodontal Pockets Depth (PPD), Gingival Recession (GR) and Clinical Attachment Loss (CAL). The assessment of (PLI) and(GI) was four sites around each tooth, whereas, the assessment of PPD, GR and CAL were six sites around each tooth to the next millimeter utilizing University of Michigan O probe with Williams markings (Figures 3-5). 


\section{Questionnaire Part I\& II:}

\section{Caregivers' periodontal and oral health knowledge and awareness}

No. Participant (Caregivers):

Study Group: First:

Age:

Gender:
File number:

Third:

\begin{tabular}{|c|c|c|}
\hline No & Questions & Choose only One Answer? \\
\hline \multirow{4}{*}{1} & \multirow{4}{*}{ How many teeth does adult individual have? } & A-18. \\
\hline & & B-28. \\
\hline & & $\mathrm{C}-32$. \\
\hline & & D- I haven't any idea. \\
\hline \multirow[t]{4}{*}{2} & \multirow{4}{*}{$\begin{array}{l}\text { Which of the following may help you to } \\
\text { know the dental decay? }\end{array}$} & $\begin{array}{l}\text { A-Small black cavity on the } \\
\text { tooth surface. }\end{array}$ \\
\hline & & B-Tooth bleeding. \\
\hline & & C-Tooth pain. \\
\hline & & D.I haven't any idea. \\
\hline \multirow{4}{*}{3} & \multirow{4}{*}{$\begin{array}{l}\text { Do you know what the discoloration in the } \\
\text { neck of the tooth is? }\end{array}$} & A-Plaque. \\
\hline & & B-Tartar. \\
\hline & & C-Food debris. \\
\hline & & D- I haven't any idea. \\
\hline \multirow{4}{*}{4} & \multirow{4}{*}{ What do bleeding gums indicate? } & A-Normal Gum. \\
\hline & & B-Infected Gums. \\
\hline & & C-Pigmented Gums. \\
\hline & & D-I haven't any idea. \\
\hline \multirow{4}{*}{5} & \multirow{4}{*}{$\begin{array}{l}\text { Which of the following is considered } \\
\text { essential for causing gum diseases? }\end{array}$} & A- Age progression. \\
\hline & & B-Sweet and sugar. \\
\hline & & C-Bacterial deposit. \\
\hline & & D- I haven't any idea. \\
\hline \multirow{4}{*}{6} & \multirow{4}{*}{$\begin{array}{l}\text { Which of the following may occur after } \\
\text { gums diseases? }\end{array}$} & A-Gums abscess. \\
\hline & & B-Missing teeth. \\
\hline & & C-Headache. \\
\hline & & D-I haven't any idea. \\
\hline \multirow{3}{*}{7} & \multirow{3}{*}{$\begin{array}{l}\text { Do you think, there is a correlation between } \\
\text { systemic diseases and gum diseases? }\end{array}$} & A-Yes. \\
\hline & & B-No. \\
\hline & & C-I haven't any idea. \\
\hline \multirow{4}{*}{8} & \multirow{4}{*}{$\begin{array}{l}\text { What is the most important problem related } \\
\text { to the gums and teeth of your patient? }\end{array}$} & A-Bleeding of gums. \\
\hline & & B-Dental decay. \\
\hline & & C-Movement of teeth. \\
\hline & & D-I haven't any idea. \\
\hline \multirow{4}{*}{9} & \multirow{4}{*}{$\begin{array}{l}\text { Which of the following food most } \\
\text { deleterious to teeth and gums? }\end{array}$} & A-Sweet. \\
\hline & & B-Meat. \\
\hline & & C-Fruits \\
\hline & & D-I haven't any idea. \\
\hline \multirow{4}{*}{10} & \multirow{4}{*}{$\begin{array}{l}\text { What are the effects of tobacco smoking on } \\
\text { the gums? }\end{array}$} & A- Mouth sensation. \\
\hline & & B-Inflammation of gums. \\
\hline & & C- Mouth cancer. \\
\hline & & D-I haven't any idea. \\
\hline
\end{tabular}

Figure 1. Questionnaire Part I \& II: Caregivers periodontal and oral health knowledge and awareness.

\subsection{Statistical Analysis}

Data was collected and a comparison was done between the oral health practice and knowledge level of caregivers and periodontal status of special needs adults. Data was analyzed by using the SPSS Statistical Software (version 21.0, IBM SPSS Inc., Chicago, IL, USA). Percentages of the results and proportions were applied to explain the statistics. Analysis of variance (ANOVA) and utilized to assess the variations in the mean and standard deviation $( \pm \mathrm{SD})$ of PLI, GI, PPD, GR and 
Questionnaire Part I \&III:

Caregivers' periodontal and oral healthpractice

No. Participant (Caregivers):

Second:

File number:

Study Group: First:

Third:

Age:

Gender:

\begin{tabular}{|c|c|c|}
\hline No. & Questions & Choose only One Answer \\
\hline \multirow{4}{*}{1} & \multirow{4}{*}{ What is the ideal method for teeth cleaning at home? } & A-Tooth brushing. \\
\hline & & B-Washing with water. \\
\hline & & C- Cleaning with Miswak. \\
\hline & & D-I haven't any idea. \\
\hline \multirow{4}{*}{2} & \multirow{4}{*}{ How many times per day the teeth should be cleaned? } & A-One-time. \\
\hline & & B-Two times. \\
\hline & & C-After eating. \\
\hline & & D-I haven't any idea. \\
\hline \multirow{4}{*}{3} & \multirow{4}{*}{ What Kind of dentifrices do you prefer? } & $\begin{array}{l}\text { A-Anti-Sensitive teeth } \\
\text { dentifrices. }\end{array}$ \\
\hline & & $\begin{array}{l}\text { B-Teeth-whitening } \\
\text { dentifrices. }\end{array}$ \\
\hline & & C-Herbal dentifrices. \\
\hline & & D-I haven't any idea. \\
\hline \multirow{4}{*}{4} & \multirow{4}{*}{ What is the ideal kind of tooth brush? } & A-Soft. \\
\hline & & B-Medium. \\
\hline & & C-Hard. \\
\hline & & D-I haven't any idea. \\
\hline \multirow{4}{*}{5} & \multirow{4}{*}{$\begin{array}{l}\text { Which of the following is the correct method of tooth } \\
\text { brushing? }\end{array}$} & A-Horizontal. \\
\hline & & B-Circular. \\
\hline & & C- Horizontal with circular. \\
\hline & & D-I haven't any idea. \\
\hline \multirow{4}{*}{6} & \multirow{4}{*}{ When the toothbrush should be changed? } & A-After one month. \\
\hline & & B-After 2 months. \\
\hline & & C-After 3 months. \\
\hline & & D-I haven't any idea. \\
\hline \multirow{4}{*}{7} & \multirow{4}{*}{$\begin{array}{l}\text { Which of the following should be used for cleaning the } \\
\text { spaces between teeth? }\end{array}$} & A-The dental floss. \\
\hline & & B-The toothpick. \\
\hline & & C-Inter dental brush. \\
\hline & & D-I haven't any idea. \\
\hline \multirow{4}{*}{8} & \multirow{4}{*}{ What is the suitable time to visit the dental clinic routinely } & A-Once every 3 months. \\
\hline & & B- Once every 6 months. \\
\hline & & C-Once every year. \\
\hline & & D-I haven't any idea \\
\hline
\end{tabular}

Figure 2. Questionnaire Part I \& III: Caregivers periodontal and oral health practice.

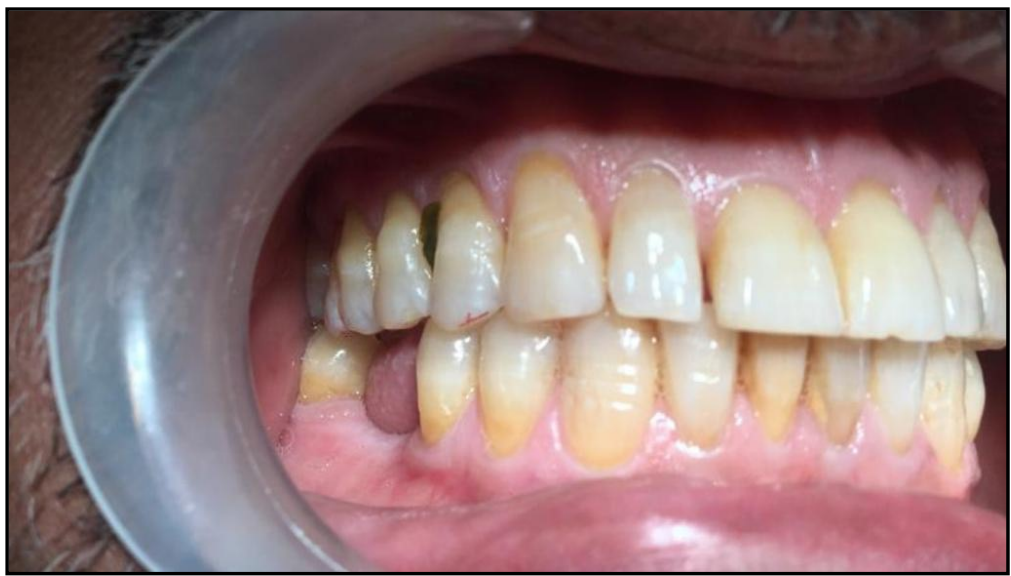

Figure 3. Periodontal status of disability patient within group I. 


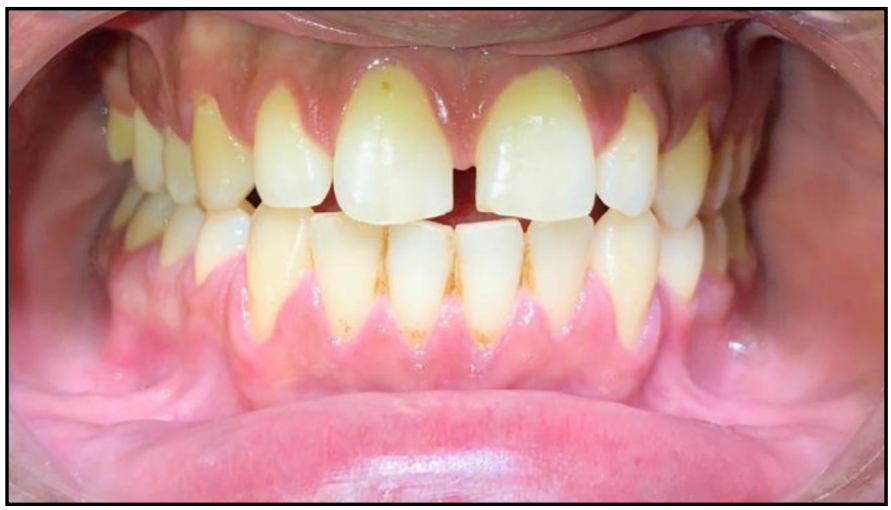

Figure 4. Periodontal status of disability patient within group II.

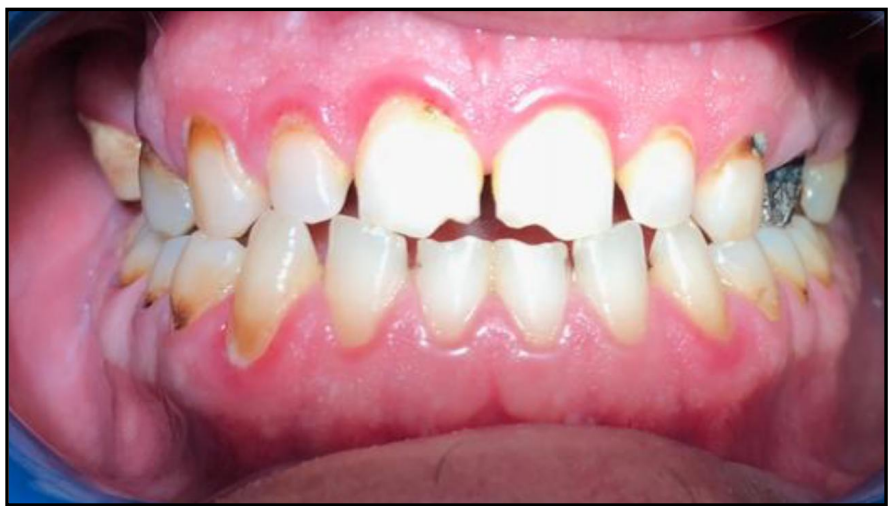

Figure 5. Periodontal status of disability patient within group III.

CAL. Chi-square test was applied to evaluate the relation between periodontal and oral hygiene status of patients. According to the types of disabilities and caregiver oral health practice, knowledge level and the adopted statistical significance differences ( $p$-value) in the results of this study were $(\mathrm{p}<0.05)$.

\section{Results}

Table 1 and Figure 6 display that the participants in the present study were 180 of special needs individuals and 180 caregivers within three different groups ( $\mathrm{n}=$ $60+60+60$ ). Special needs individuals had a range of age between 24 and 75 years. Whereas caregivers had a range of age between 25 and 55 years. Approximately, $29 \%$ of group I, $33 \%$ of group II and $32 \%$ of group III were in the early adulthood age. $38 \%$ of group I, $37 \%$ of group II and $45 \%$ of group III were in the moderate adulthood age. Furthermore, $33 \%$ of group I, $30 \%$ of group II and $23 \%$ of group III were in the later adulthood age.

On the other hand, Table 2 and Figure 7 summarize the distributions of group I, II and III caregivers within the range age 25 - 35 years, 36 - 45 years and 46 - 55 years. These findings within Table 2 and Figure 7 showed that $20 \%$ of group I, $28 \%$ of group II, $19 \%$ of group III were within the age range of 25 - 35 years. $45 \%$ of group I, $52 \%$ group II, and $48 \%$ of group III were within the range of age 36 - 45 years, moreover, $21 \%$ of group I, $20 \%$ of group II, and $33 \%$ 
Table 1. Patients age range and distribution of special needs individuals.

\begin{tabular}{ccccc}
\hline \multirow{2}{*}{ DA $^{\ddagger}$} & \multicolumn{3}{c}{ Groups } & \multirow{2}{*}{ Total } \\
\cline { 2 - 4 } & Group I & Group II & Group III & \\
\hline EA & $17(29 \%)$ & $20(33 \%)$ & $19(32 \%)$ & $56(31 \%)$ \\
MA & $23(38 \%)$ & $22(37 \%)$ & $27(45 \%)$ & $72(40 \%)$ \\
LA & $20(33 \%)$ & $18(30 \%)$ & $14(23 \%)$ & $52(29 \%)$ \\
Total & $60(100 \%)$ & $60(100 \%)$ & $60(100 \%)$ & $180(100 \%)$ \\
& $X^{2}$ & & 5.204 & \\
Chi-square & P-value & & 0.103 & \\
\hline
\end{tabular}

${ }^{\dagger}$ Distributions of adults within group; ${ }^{*}$ Early Adulthood (24 - 34 ys); ${ }^{* *}$ Moderate Adulthood; ${ }^{* *}(34-60$ ys). ${ }^{\varphi}$ Later Adulthood (60 - 75 ys).

Table 2. Patients age range and distribution of health caregivers.

\begin{tabular}{|c|c|c|c|c|c|c|}
\hline & & & \multicolumn{3}{|c|}{ Groups } & \multirow{2}{*}{ Total } \\
\hline & & & Group I & Group II & Group III & \\
\hline \multirow{3}{*}{ Range of age } & 25 - 35 ys & & $12(20 \%)$ & $17(28 \%)$ & $11(19 \%)$ & $40(23 \%)$ \\
\hline & $36-45$ ys & & $27(45 \%)$ & $31(52 \%)$ & $29(48 \%)$ & $87(48 \%)$ \\
\hline & $46-55$ ys & & $21(35 \%)$ & $12(20 \%)$ & $20(33 \%)$ & $53(29 \%)$ \\
\hline \multicolumn{2}{|c|}{ Total } & & $60(100 \%)$ & $60(100 \%)$ & $60(100 \%)$ & $180(100 \%)$ \\
\hline \multirow{2}{*}{\multicolumn{2}{|c|}{ Chi-square }} & $X^{2}$ & \multicolumn{4}{|c|}{4.725} \\
\hline & & $\mathrm{P}$-value & \multicolumn{4}{|c|}{0.146} \\
\hline
\end{tabular}

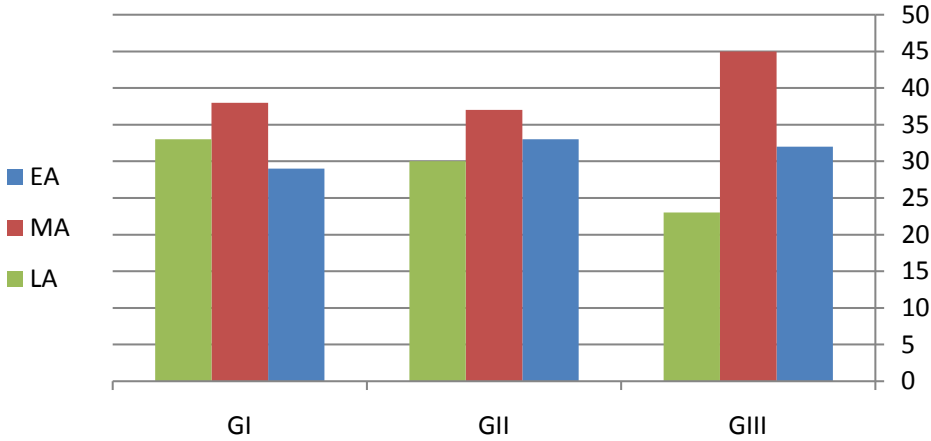

Figure 6. Patients age range and distribution of special needs individuals.

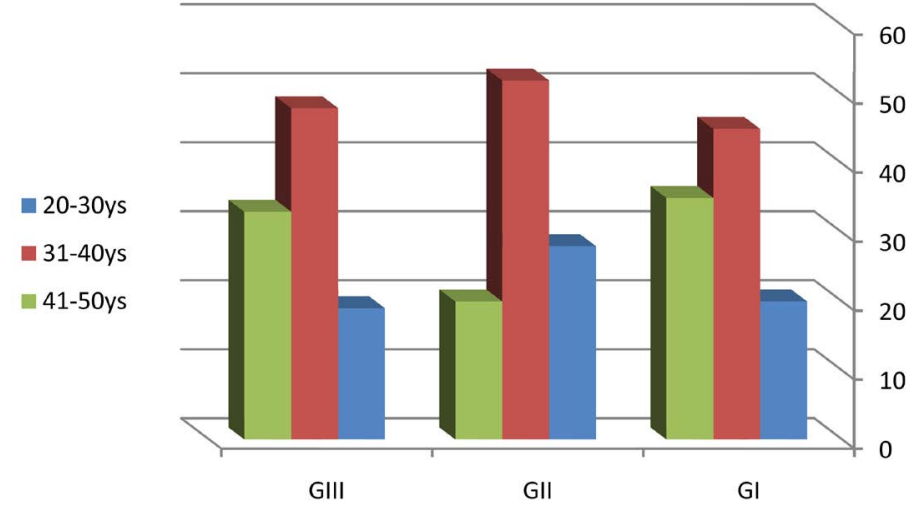

Figure 7. Patients age range and distribution of health caregivers. 
of group III were within the range of age 46 - 55 years. Consequently and according to these results, there were $31 \%, 40 \%$ and $29 \%$ of special needs individuals within early Adulthood age. The moderate adulthood age, and the later adulthood age respectively, whereas, $23 \%, 48 \%$ and $29 \%$ of caregivers within the age range of 25 - 35 years 36 - 45 years and 46 - 55 years respectively.

Caregivers were interviewed to evaluate their periodontal and oral health knowledge and awareness (Table 3 ) and their periodontal and oral health practice (Table 4). That was according to the design of the current study and through the answers of questions in the questionnaire.

Table 3 shows that all caregivers in all groups chose the correct answers to the questions that evaluated the periodontal, oral health knowledge and awareness except the answer to question number six, where $51 \%$ and $59 \%$ of caregivers in group I and III chose the wrong answers to compare with 55\% of them chose the correct answers in group II. Generally, there were good periodontal and oral health knowledge and awareness among caregivers, particularly in group II more than group III and group I and this knowledge among the caregivers in the group III was better than the knowledge among the caregivers in group I.

Table 4 demonstrates the answers of questions about the caregivers periodontal and oral health practice in group I, II and III respectively. Where it turns out $55 \%$ of group I, $68 \%$ of group II and $72 \%$ of group III reported that tooth brushing is the ideal method for teeth cleaning at home.

Tooth brushing should be two times daily according to the answers of $37 \%$ of group I, $32 \%$ of group II and $49 \%$ of group III compared to $48 \%$ of group I, $16 \%$ of group II and $16 \%$ of group III who reported that it should be after eating. Furthermore, the anti-sensitivity teeth dentifrices were the best toothpaste according to the answers of $69 \%$ of group I, $78 \%$ of group II and $70 \%$ of group III.

On the other hand, $55 \%$ of group I, $27 \%$ of group II and $52 \%$ of group III answered that the ideal brush is the soft toothbrushes compare with $37 \%$ group I, $57 \%$ of group II and $45 \%$ of group III who chose the answer of medium toothbrushes. In addition, $33 \%, 60 \%$ and $48 \%$ of caregivers demonstrated that the toothbrush should be changed every three months. Regarding the answers to oral hygiene measures in the questionnaire and when we asked caregivers about the right method of tooth brushing $38 \%$ of group I, $52 \%$ of group II and $55 \%$ of group III reported that the horizontal tooth brushing is the best method.

In the answers to the question about the methods of interdental spaces cleaning, $73 \%$ of group I, $77 \%$ of group II and $77 \%$ of group III answered that the using to dental floss is the effective method to clean the Interdental space. Regarding determine the suitable time of the dental clinic visit, there were $63 \%$ of group I, $72 \%$ of group II and $60 \%$ of group III answered that it should be every six months. Consequently, oral health practice among the caregivers of group II and group III was better than among the caregivers of group I.

Table 5 and Figure 8 reveal the mean and standard deviation of PLI, GI, PPD, GR and CAL of the patients in the present study groups. There were differences without statistical significance in all clinical parameters between group I, group 
Table 3. Caregivers periodontal and oral health knowledge and awareness

\begin{tabular}{|c|c|c|c|c|c|c|c|c|c|}
\hline \multirow{2}{*}{$\mathrm{N}$} & \multirow{2}{*}{ Questions } & \multirow{2}{*}{ Choose one answer } & \multicolumn{3}{|c|}{ Frequency } & \multicolumn{3}{|c|}{$\%$} & \multirow[t]{2}{*}{$\mathrm{P}$ value } \\
\hline & & & GI & GII & GIII & GI & GII & GIII & \\
\hline \multirow{5}{*}{1} & \multirow{5}{*}{$\begin{array}{l}\text { How many teeth } \\
\text { does adult individual } \\
\text { have? }\end{array}$} & A-18 & 0 & 0 & 0 & 0 & 0 & 0 & \multirow{5}{*}{$0.0001^{*}$} \\
\hline & & B-28 & 0 & 6 & 6 & 0 & 10 & 10 & \\
\hline & & & & & & & & & \\
\hline & & C-32 & 49 & 47 & 42 & 82 & 78 & 80 & \\
\hline & & D-I haven't any idea & 11 & 7 & 6 & 18 & 12 & 10 & \\
\hline \multirow{4}{*}{2} & \multirow{4}{*}{$\begin{array}{l}\text { Which of the } \\
\text { following may help } \\
\text { you to know the } \\
\text { dental decay? }\end{array}$} & $\begin{array}{l}\text { A-Small black cavity on } \\
\text { the tooth surface }\end{array}$ & 58 & 55 & 56 & 97 & 92 & 93 & \multirow{4}{*}{$0.0001^{\star}$} \\
\hline & & B-Tooth bleeding & 0 & 0 & 0 & 0 & 0 & 0 & \\
\hline & & C-Tooth pain & 2 & 5 & 4 & 3 & 8 & 7 & \\
\hline & & D-I haven't any idea & 0 & 0 & 0 & 0 & 0 & 0 & \\
\hline \multirow{4}{*}{3} & \multirow{4}{*}{$\begin{array}{l}\text { Do you know what } \\
\text { the discoloration in } \\
\text { the neck of the tooth } \\
\text { is? }\end{array}$} & A-Plaque & 49 & 52 & 51 & 82 & 87 & 85 & \multirow{4}{*}{$0.0001^{\times}$} \\
\hline & & B-Tartar & 0 & 0 & 3 & 0 & 0 & & \\
\hline & & C-Food debris & 6 & 5 & 4 & 10 & 8 & 7 & \\
\hline & & D-I haven't any idea & 5 & 3 & 2 & 8 & 5 & 3 & \\
\hline \multirow{4}{*}{4} & \multirow{4}{*}{$\begin{array}{l}\text { What do bleeding } \\
\text { gums indicate? }\end{array}$} & A-Normal Gum & 0 & 0 & 0 & 0 & 0 & 0 & \multirow{4}{*}{$0.0001^{\rtimes}$} \\
\hline & & B-Infected Gums & 52 & 58 & 56 & 87 & 97 & 93 & \\
\hline & & C-Pigmented Gums & 5 & 0 & 3 & 8 & 0 & 5 & \\
\hline & & D-I haven't any idea & 3 & 2 & 1 & 5 & 3 & 2 & \\
\hline \multirow{4}{*}{5} & \multirow{4}{*}{$\begin{array}{l}\text { Which of the } \\
\text { following is } \\
\text { considered essential } \\
\text { for causing gum } \\
\text { diseases? }\end{array}$} & A-Age progression & 0 & 0 & 0 & 0 & 0 & 0 & \multirow{4}{*}{$0.0001^{\rtimes}$} \\
\hline & & B-Sweet and sugar & 15 & 12 & 16 & 25 & 20 & 27 & \\
\hline & & C-Bacterial deposit & 41 & 48 & 44 & 68 & 80 & 73 & \\
\hline & & D-I haven't any idea & 4 & 0 & 0 & 7 & 0 & 0 & \\
\hline \multirow{4}{*}{6} & \multirow{4}{*}{$\begin{array}{l}\text { Which of the } \\
\text { following may occur } \\
\text { after gums diseases? }\end{array}$} & A-Gums abscess & 31 & 22 & 35 & 51 & 36 & 59 & \multirow{4}{*}{$0.0001^{\rtimes}$} \\
\hline & & B-Missing teeth & 21 & 33 & 20 & 35 & 55 & 33 & \\
\hline & & C-Headache & 4 & 1 & 0 & 7 & 2 & 0 & \\
\hline & & D-I haven't any idea & 4 & 4 & 5 & 7 & 7 & 8 & \\
\hline & $\begin{array}{l}\text { Do you think, there } \\
\text { is a correlation }\end{array}$ & A-Yes & 39 & 41 & 40 & 65 & 68 & 66 & \multirow{3}{*}{$0.0001^{\rtimes}$} \\
\hline 7 & between systemic & B-No & 14 & 6 & 7 & 23 & 10 & 12 & \\
\hline & $\begin{array}{l}\text { diseases and gum } \\
\text { diseases? }\end{array}$ & C-I haven't any idea & 7 & 13 & 13 & 12 & 22 & 22 & \\
\hline & What is the most & A-Bleeding of gums & 29 & 22 & 20 & 48 & 36 & 33 & \\
\hline 8 & $\begin{array}{l}\text { important problem } \\
\text { related to the gums }\end{array}$ & B-Dental decay & 20 & 25 & 28 & 33 & 42 & 47 & 0.00001 \\
\hline & and teeth of your & C-Movement of teeth & 4 & 7 & 6 & 7 & 12 & 10 & * \\
\hline & patient? & D-I haven't any idea & 7 & 6 & 6 & 12 & 10 & 10 & \\
\hline & & A-Sweet & 55 & 49 & 52 & 92 & 81 & 86 & \\
\hline 9 & $\begin{array}{l}\text { Which of the } \\
\text { following food most }\end{array}$ & B-Meat & 0 & 7 & 4 & 0 & 12 & 7 & \\
\hline (3) & deleterious to teeth & C-Fruits & 0 & 0 & 4 & 0 & 0 & 7 & .0001 \\
\hline & & D-I haven't any idea & 5 & 4 & 0 & 8 & 7 & 0 & \\
\hline
\end{tabular}




\section{Continued}

\begin{tabular}{lcccccccc}
\hline A-Mouth sensation & 5 & 2 & 4 & 8 & 3 & 7 & \\
$\begin{array}{l}\text { What are the effects B-Inflammation of gums } \\
\text { of tobacco smoking }\end{array}$ & 10 & 14 & 10 & 16 & 23 & 16 & \\
$\begin{array}{l}\text { on the gums? } \\
\text { C-Mouth cancer }\end{array}$ & 39 & 40 & 43 & 64 & 67 & 72 & $0.0001^{*}$ \\
D-I haven't any idea & 7 & 4 & 3 & 12 & 7 & 5 & \\
\hline
\end{tabular}

Table 4. Caregivers periodontal and oral health practice.

\begin{tabular}{|c|c|c|c|c|c|c|c|c|}
\hline \multirow{2}{*}{$\mathrm{N}$} & \multirow{2}{*}{ questions } & \multirow{2}{*}{ Choose one answer } & \multicolumn{3}{|c|}{ Frequency } & \multicolumn{3}{|c|}{$\%$} \\
\hline & & & GI & GII & GIII & GI & GII & GIII \\
\hline \multirow{4}{*}{1} & \multirow{4}{*}{$\begin{array}{l}\text { What is the ideal } \\
\text { method for teeth } \\
\text { cleaning at home? }\end{array}$} & A-Tooth brushing & 33 & 41 & 43 & 55 & 68 & 72 \\
\hline & & B-Washing with water & 21 & 1 & 2 & 35 & 2 & 3 \\
\hline & & C-Cleaning with Miswak & 4 & 17 & 13 & 7 & 28 & 22 \\
\hline & & D-I haven't any idea & 2 & 1 & 2 & 3 & 2 & 3 \\
\hline \multirow{4}{*}{2} & \multirow{4}{*}{$\begin{array}{l}\text { How many times per } \\
\text { day the teeth should be } \\
\text { cleaned? }\end{array}$} & A-One-time & 4 & 28 & 20 & 7 & 47 & 33 \\
\hline & & B-Two times & 22 & 19 & 29 & 37 & 32 & 49 \\
\hline & & C-After eating & 29 & 10 & 10 & 48 & 16 & 16 \\
\hline & & D-I haven't any idea & 5 & 3 & 1 & 8 & 5 & 2 \\
\hline \multirow{4}{*}{3} & \multirow{4}{*}{$\begin{array}{l}\text { What Kind of } \\
\text { dentifrices do you } \\
\text { prefer? }\end{array}$} & A-Anti-sensitivity dentifrices & 41 & 47 & 42 & 69 & 78 & 70 \\
\hline & & B-Teeth-whitening dentifrices & 8 & 2 & 5 & 13 & 3 & 8 \\
\hline & & C-Herbal dentifrices & 3 & 4 & 5 & 5 & 7 & 8 \\
\hline & & D-I haven't any idea & 8 & 7 & 8 & 13 & 12 & 14 \\
\hline \multirow{4}{*}{4} & \multirow{4}{*}{$\begin{array}{l}\text { What is the ideal kind } \\
\text { of toothbrush? }\end{array}$} & A-Soft & 33 & 16 & 31 & 55 & 27 & 52 \\
\hline & & B-Medium & 22 & 34 & 27 & 37 & 57 & 45 \\
\hline & & C-Hard & 5 & 10 & 0 & 8 & 16 & 0 \\
\hline & & D-I haven't any idea & 0 & 0 & 2 & 0 & 0 & 3 \\
\hline \multirow{4}{*}{5} & & A-Horizontal & 23 & 31 & 33 & 38 & 52 & 55 \\
\hline & Which of the following & B-Circular & 14 & 16 & 16 & 23 & 26 & 26 \\
\hline & of tooth brushing? & C- Horizontal with circular & 16 & 12 & 7 & 27 & 20 & 12 \\
\hline & & D-I haven't any idea & 7 & 1 & 4 & 12 & 2 & 7 \\
\hline \multirow{4}{*}{6} & \multirow{4}{*}{$\begin{array}{l}\text { When the toothbrush } \\
\text { should be changed? }\end{array}$} & A-After one month & 16 & 13 & 13 & 27 & 22 & 22 \\
\hline & & B-After 2 months & 23 & 10 & 17 & 38 & 16 & 28 \\
\hline & & C-After 3 months & 20 & 36 & 29 & 33 & 60 & 48 \\
\hline & & D-I haven't any idea & 1 & 1 & 1 & 2 & 2 & 2 \\
\hline \multirow{4}{*}{7} & \multirow{4}{*}{$\begin{array}{l}\text { Which of the following } \\
\text { should be used for } \\
\text { cleaning the spaces } \\
\text { between teeth? }\end{array}$} & A-The dental floss & 44 & 46 & 46 & 73 & 77 & 77 \\
\hline & & B-The toothpick & 8 & 8 & 5 & 13 & 13 & 8 \\
\hline & & C-Inter dental brush & 7 & 5 & 8 & 12 & 8 & 13 \\
\hline & & D-I haven't any idea & 1 & 1 & 1 & 2 & 2 & 2 \\
\hline \multirow{4}{*}{8} & \multirow{4}{*}{$\begin{array}{l}\text { What is the suitable } \\
\text { time to visit the dental } \\
\text { clinic routinely }\end{array}$} & A-Once every 3 months & 8 & 8 & 13 & 13 & 13 & 22 \\
\hline & & B-Once every 6 months & 38 & 43 & 36 & 63 & 72 & 60 \\
\hline & & C-Once every year & 13 & 8 & 10 & 22 & 13 & 16 \\
\hline & & D-I haven't any idea & 1 & 1 & 1 & 2 & 2 & 2 \\
\hline
\end{tabular}


Table 5. Mean and standard deviation $( \pm S D)$ of clinical findings.

\begin{tabular}{cccccc}
\hline & $\mathrm{PLI}^{\times}$ & $\mathrm{GI}^{\mathrm{x}}$ & $\mathrm{PPD}^{\circ}$ & $\mathrm{GR}^{\omega 0}$ & $\mathrm{CAL}^{v}$ \\
\hline Group I & $1.3 \pm 0.2$ & $1.5 \pm 0.7$ & $4.5 \pm 0.81$ & $2.1 \pm 0.33$ & $6.6 \pm 1.14$ \\
Group II & $1.9 \pm 0.7$ & $1.7 \pm 0.11$ & $6.0 \pm 1.5$ & $2.7 \pm 0.88$ & $8.7 \pm 2.38$ \\
Group III & $2.0 \pm 0.6$ & $2.5 \pm 1.6$ & $5.5 \pm 1.5$ & $2.0 \pm 0.25$ & $7.5 \pm 1.75$ \\
P-value & 0.613 & 0.355 & 0.314 & 0.677 & 0.424
\end{tabular}

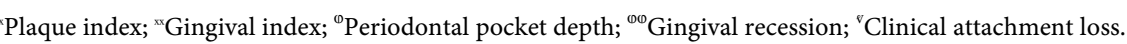

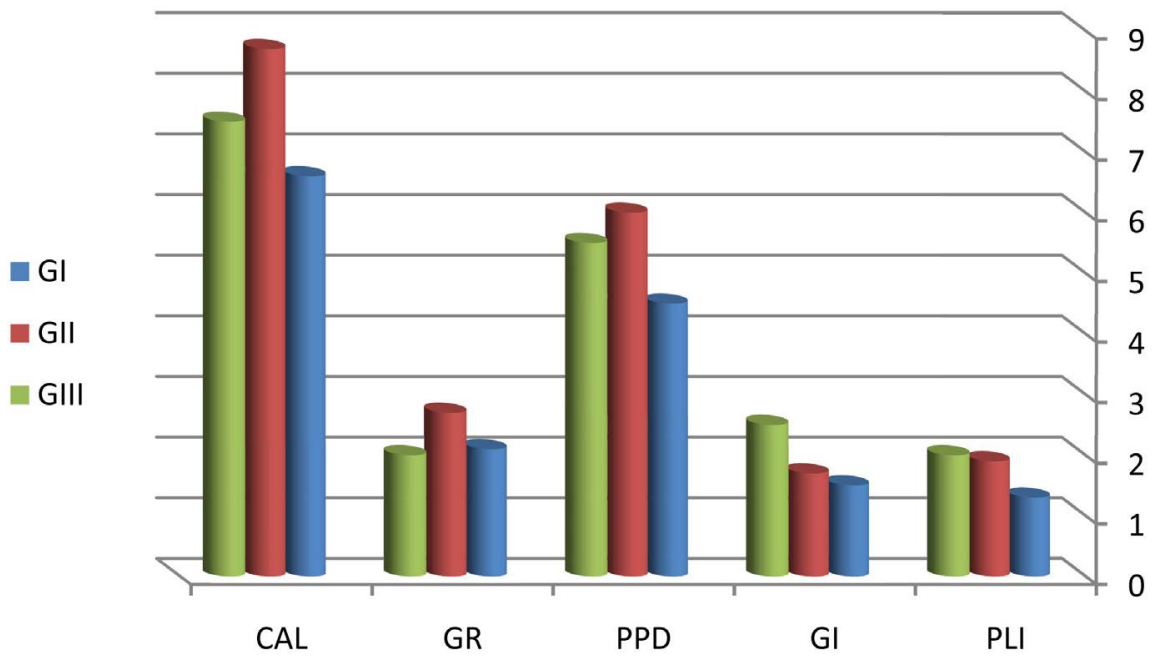

Figure 8. Mean and standard deviation $( \pm S D)$ of clinical findings.

II group III $(p>0.05)$. The mean and standard deviation of PLI and GI of group III were more than group I and II whereas PPD, GR and CAL in group II were more than group I and group III.

Patients in group I and group III had a fair oral hygiene and Stage III generalized periodontitis moderate rate, whereas, moderate oral hygiene and Stage III generalized periodontitis severe rate were detected among the patients in group II. These clinical findings are not corresponding to the oral health knowledge and practice among caregivers of group I, group II and III where there was an increase in the level of oral health knowledge and practice among caregivers of group II and group III more than group I.

\section{Discussions}

The role of caregivers in the preservation of periodontal and oral health is very important. Consequently, regular oral health participates to the inhibition of periodontal disease, but there are difficulties for the individuals with special needs who cannot do regular oral health by themselves and depend on caregivers for help.

Special needs individuals were divided into two main groups: Congenital deficiencies group and acquired disorders group. The current study was designed to assess the effect of oral health practice and knowledge level of caregivers on pe- 
riodontal status of some special needs adults in Aseer Region, Saudi Arabia. Several earlier studies revealed that there was sufficient knowledge of oral health among caregivers [22] [23], particularly in periodontal health knowledge [24].

In Saudi Arabia and depending on the knowledge of authors, there are no former studies displayed the relationship between the periodontal status of special needs individuals and the oral health Knowledge of their caregivers in Aseer Region. The findings of the present study displayed differences in periodontal status among special needs individuals according to the oral health knowledge and oral health practice among caregivers. These results are in agreement with the results of another study which demonstrated that good oral health could be accomplished for special needs individuals after caregivers' development of their oral health knowledge [25].

The findings of the present study revealed that the caregivers had a good knowledge about oral health $(81.75 \%)$ more than their knowledge of periodontal health $(67.5 \%)$, which is in agreement with the finding of another study which revealed that $75 \%$ of the caregivers reported that constant oral health is necessary to avoid the incidence of oral diseases [26]. However, the results of the present study displayed that oral health knowledge of caregivers and their periodontal health knowledge did not affect the periodontal status among special needs individuals.

In the present study $70.5 \%$ of caregivers in group I chose the correct answers of oral health and periodontal knowledge questions, compared to $74.7 \%$ of group II and $72.8 \%$ of group III. This shows that the caregivers of the special needs individuals in the current study had more awareness about the risk factors of oral and periodontal diseases.

In a previous study which has been done to evaluate the oral health knowledge of some caregivers, there were three from five of caregivers knew the effects of topical application of fluoride in preventing dental caries. Other previous studies confirmed the importance of caregiver's comprehension regarding the effect of fluoride in the protection of oral health [27] [28]. These results are consistent with the results of the current study where found that $69 \%$ of caregivers in group I, 78\% of caregivers in group II and $70 \%$ of caregivers in group III answered that anti-sensitivity teeth dentifrices should be used.

It is noteworthy that caregivers in this study demonstrated acceptable knowledge of periodontal and oral health practice, where $37 \%$ of caregivers in group I, $32 \%$ of caregivers in group II and $49 \%$ of caregivers in group III answered that teeth should be brushed twice daily. In contrast with $48 \%$ of caregivers in group I, $16 \%$ of caregivers in group II and $16 \%$ of caregivers in group III relieved that it is best to brush teeth after every meal. Moreover, $7 \%$ of caregivers in group I, $47 \%$ of caregivers in group II and $33 \%$ of caregivers in group III answered that teeth should be brushed one time daily. These results are in agreement with a professional recommendation which revealed that tooth brushing should be twice daily with bass technique [29].

On the other hand, the results aren't in agreement with the findings of Niazi 
et al. [30], who demonstrated that $50 \%$ of caregivers used Miswak as toothbrush, whereas, in the current study 55\% in group I, $68 \%$ in group II and $72 \%$ in group III reported that toothbrush is more effective than Miswak. In addition, most of the participants in the present study answered that they changed their toothbrush every three months, which is corresponding with earlier studies exhibited that $65.5 \%$ of participants changed their toothbrush every three months [31].

Considering that the toothbrushes are vital tools in plaque controlling and keeping of periodontal health [32] [33]. The questionnaire in the present study included asking the caregivers about the kinds of toothbrushes. It showed that about $55 \%, 27 \%$ and, $52 \%$ of caregivers in group I, II and III respectively used soft toothbrushes. Compared to $37 \%, 57 \%$ and, $45 \%$ of caregivers in group I, II and II who respectively used medium toothbrushes. Moreover, $10 \%$ and $16 \%$ in group I and II used hard toothbrushes. Caregivers in the current study favored soft toothbrushes based on dental professionals' recommendation that is according to the answers of them [34].

Regarding the method of tooth brushing, the plurality of caregivers in the present study used horizontal tooth brushing technique. These results coincided with the results of Padilla et al. studies [35].

It should be noted that to preserve the health of periodontal tissues in interdental areas, many researchers recommend using dental floss [36]. According to the results of the present study, $73 \%, 77 \%$ and $77 \%$ of caregivers in group I, II and III respectively, reported that using the dental floss is the appropriate method to prevent the health of periodontal tissues in interdental areas.

Based on the results of the current study, there were ineffectual of oral health Knowledge and oral health practices of caregivers to decrease the formation of dental plaque and periodontal disease among special needs individuals in Aseer region. In previous epidemiological study, there was a relation between the level of dental plaque and oral hygiene in addition to the severity of periodontal disease [37].

According to the clinical findings of the present study, the oral hygiene is better and severity of periodontal diseases is less among the special needs individuals in group I compared to the special needs individuals in group II and group III.

In the present study, the oral hygiene was fair and the severity of periodontal disease was stage III generalized periodontitis moderate rate among the special needs individuals in group I and group III. Compared to moderate oral hygiene and severe stage III generalized periodontitis severe rate among the special needs individuals in group II [38] [39] [40].

These results are not in harmony with the oral health knowledge and practice among caregivers of group I, group II and III, where there was an increase in the level of oral health knowledge and practice among caregivers of group II more than group I and group III. That may be due to the mental retardation among the patients of group II compared to the patients of group I and III. 


\section{Limitations of the Study}

The limitations in this study are that it was carried out on the special needs individuals who went through periodontal treatment in the outpatient Dental Clinics, College of Dentistry, King Khalid University in Abha city as a sample of special needs individuals in Aseer region. It is known that there are several centers of special needs individuals in Saudi Arabia. Moreover, this study included males of caregivers and special needs individuals only.

\section{Conclusion}

Although the limitations in the present study conclude that all caregivers didn't take practice in periodontal and oral care, and they educated periodontal oral health practice by other colleagues or by themselves. Periodontal and oral health knowledge of caregivers was satisfying, but the periodontal status was unsatisfying that most of the special needs adults in the current study affected by moderate to severe periodontitis. For improving oral health and periodontal status of special needs individuals, the dental education and oral hygiene practice should be given to caregivers.

\section{Acknowledgements}

The authors would like to thank the parents of the special needs individuals, their caregivers, and the dental assistants in the clinics of college of dentistry, King Khalid University, for their participation and help in completing this study.

\section{Conflicts of Interest}

The authors declare no conflicts of interest regarding the publication of this paper.

\section{References}

[1] Bhambal, A., Jain, M., Saxena, S. and Kothari, S. (2011) Oral Health Preventive Protocol for Mentally Disabled Subjects-A Review. Journal of Advanced Oral Research, 1, 21-26. https://doi.org/10.1177/2229411220110105

[2] Watt, R.G. (2005) Strategies and Approaches in Oral Disease Prevention and Health Promotion. Bulletin of the World Health Organization, 3, 711-718.

[3] Gabre, P., Martinsson, T. and Gahnberg, L. (1999) Incidence of, and Reasons for, Tooth Mortality among Mentally Retarded Adults during a 10-Year Period. Acta Odontologica Scandinavica, 57, 56-61. https://doi.org/10.1080/000163599429110

[4] Bellini, H.T., Campi, R. and Denardi, J.L. (1981) Four Years of Monthly Professional Tooth Cleaning and Topical Fluoride Application in Brazilian Schoolchildren. I. Effect on Gingivitis. Journal of Clinical Periodontology, 8, 231-238. https://doi.org/10.1111/j.1600-051X.1981.tb02034.x

[5] Mclvor, F.T. and EtMachen, J.B. (1986) Prevention of Dental Disease in Handicapped People. In: Wessels, K.E., Ed., Dentistry for the Handicapped Patient, PSG Publishing Company, Lyttleton, 78-79.

[6] Watson, N. (2000) Barriers, Discrimination and Prejudice. In: Nunn, J., Ed., Disa- 
bility and Oral Care, World Dental Press Ltd., London, 15-28.

[7] Carter, G. and Jancar, J. (1983) Mortality in the Mentally Handicapped: A 50 Year Survey at the Stoke Park Group of Hospitals (1930-1980). Journal of Mental Deficiency Research, 27, 143-156. https://doi.org/10.1111/j.1365-2788.1983.tb00287.x

[8] Moulazadeh, M.A. and Al-Harbi, T.S. (2016) Design of the Built Environment and the Integration of Wheelchair Users in the Kingdom of Saudi Arabia: Commentary and Exploratory Study. Journal on Developmental Disabilities, 22, 121-137.

[9] Richmond, J.B., Butler, J.A. and Stenmark, S. (1983) Reducing Childhood Disability in the 80s. Psychiatric Services, 34, 507-514. https://doi.org/10.1176/ps.34.6.507

[10] Milaat, W. (1999) Public Health around the World: Saudi Arabia. Public Health Medicine, 1, 34-38.

[11] Hunter, B. (1987) Dental Care for Handicapped Patients. In: A Dental Practitioner's Handbook, Wright, Bristol, 6.

[12] Tesini, D.A. (1980) Age, Degree of Mental Retardation, Institutionalisation and Socio-Economic Status as Determinants in Oral Hygiene Status of Mentally Retarded Adolescents. Community Dentistry and Oral Epidemiology, 8, 355-359. https://doi.org/10.1111/j.1600-0528.1980.tb01307.x

[13] Murray, J.J. and Mcleod, J.P. (1973) The Dental Condition of Severly Subnormal Children in Three London Boroughs. British Dental Journal, 134, 380-385.

https://doi.org/10.1038/sj.bdj.4803008

[14] Nunn, J.H. and Murray, J.J. (1978) The Dental Health of Special Needs Children in Newcastle and Northumberland. British Dental Journal, 162, 9-14. https://doi.org/10.1038/sj.bdj.4806011

[15] Swallow, J.N. (1966) The Dental Management of the Physically Special Needs Children. British Dental Journal, 120, 35-39.

[16] Bonito, A.J. (2002) Executive Summary: Dental Care Considerations for Vulnerable Populations. Special Care in Dentistry, 22, 5s-10s.

[17] Friedrich, W.N. and Friedrich, W.L. (1981) Psychosocial Assets of Parents of Handicapped and Nonhandicapped Children. American Journal of Mental Deficiency, 85, 551-553.

[18] Binkley, C.J., Johnson, K.W., Abadi, M., Thompson, K., Shamblen, S.R., Young, L., et al. (2014) Improving the Oral Health of Residents with Intellectual and Developmental Disabilities: An Oral Health Strategy and Pilot Study. Evaluation and Program Planning, 47, 54-63. https://doi.org/10.1016/j.evalprogplan.2014.07.003

[19] Liu, Z., Yu, D., Luo, W., Yang, J., Lu, J., Gao, S., et al. (2014) Impact of Oral Health Behaviors on Dental Caries in Children with Intellectual Disabilities in Guangzhou, China. International Journal of Environmental Research and Public Health, 11, 11015-11027. https://doi.org/10.3390/ijerph111011015

[20] Silness, J. and Loe, H. (1964) Periodontal Disease in Pregnancy II. Correlation between Oral Hygiene and Periodontal Condition. Acta Odontologica Scandinavica, 22, 122-135. https://doi.org/10.3109/00016356408993968

[21] Loe, H. and Silness, J. (1963) Periodontal Disease in Pregnancy I. Prevalence and Severity. Acta Odontologica Scandinavica, 2, 533-551. https://doi.org/10.3109/00016356309011240

[22] Burtner, A.P., Jones, J.S., McNeal, D.R. and Low, D.W. (1990) A Survey of the Availability of Dental Services to Developmentally Disabled Persons Residing in the Community. Special Care in Dentistry, 10, 182-184. https://doi.org/10.1111/j.1754-4505.1990.tb00793.x 
[23] Frenkel, H., Harvey, I. and Needs, K. (2002) Oral Health Care Education and Its Effect on Caregivers' Knowledge and Attitudes: A Randomised Controlled Trial. Community Dentistry and Oral Epidemiology, 30, 91-100. https://doi.org/10.1034/j.1600-0528.2002.300202.x

[24] Stančić, I., Petrović, M., Popovac, A., Vasović, M. and Despotović, N. (2016) Caregivers' Attitudes, Knowledge and Practices of Oral Care at Nursing Homes in Serbia. Vojnosanitetski Pregled, 73, 668-673. https://doi.org/10.2298/VSP141001065S

[25] Munoz, N., Touger-Decker, R., Byham-Gray, L. and Maillet, J.O. (2009) Effect of an Oral Health Assessment Education Program on Nurses' Knowledge and Patient Care Practices in Skilled Nursing Facilities. Special Care in Dentistry, 29, 179-185. https://doi.org/10.1111/j.1754-4505.2009.00084.X

[26] Wyne, A., Hammad, N. and Splieth, C. (2015) Oral Health Knowledge of Health Care Workers in Special Children's Center. Pakistan Journal of Medical Sciences, 31, 164. https://doi.org/10.12669/pjms.311.6477

[27] Marinho, V., Higgins, J., Sheiham, A. and Logan, S. (2002) Fluoride Toothpastes for Preventing Dental Caries in Children and Adolescents. The Cochrane Database of Systematic Reviews, No. 1, CD002278. https://doi.org/10.1002/14651858.CD002278

[28] Alhammad, N.S. and Wyne, A.H. (2010) Caries Experience and Oral Hygiene Status of Cerebral Palsy Children in Riyadh. Odontostomatol Trop, 33, 5-9.

[29] Ganss, C., Schlueter, N., Preiss, S. and Klimek, J. (2009) Tooth Brushing Habits in Uninstructed Adults-Frequency, Technique, Duration and Force. Clinical Oral Investigations, 13, 203-208. https://doi.org/10.1007/s00784-008-0230-8

[30] Niazi, F., Naseem, M., Khurshid, Z., Zafar, M.S. and Almas, K. (2016) Role of Salvadora persica Chewing Stick (Miswak): A Natural Toothbrush for Holistic Oral Health. European Journal of Dentistry, 10, 301-308. https://doi.org/10.4103/1305-7456.178297

[31] Oberoi, S.S., Mohanty, V., Mahajan, A. and Oberoi, A. (2014) Evaluating Awareness Regarding Oral Hygiene Practices and Exploring Gender Differences among Patients Attending for Oral Prophy-Laxis. Journal of Indian Society of Periodontology, 18, 369-374. https://doi.org/10.4103/0972-124X.134580

[32] Younus, A. and Qureshi, A. (2016) Tooth Brush Changing Frequency and Associated Sociodemographic and Oral Hygiene Factors among Residents of Karachi. Journal of Dentistry and Oral Hygiene, 8, 4-11. https://doi.org/10.5897/JDOH2015.0180

[33] Sasan, D., Thomas, B., Mahalinga, B.K., Aithal, K.S. and Ramesh, P.R. (2006) Toothbrush Selection: A Dilemma? Indian Journal of Dental Research, 17, 167-170. https://doi.org/10.4103/0970-9290.29869

[34] Prabhati, G., Suhail, M.J. and Roobal, B. (2014) Comparative Evaluation of Plaque Removal and Soft Tissue Trauma after Use of Manual Toothbrushes with Different Bristle Stiffness. International Journal of Development Research, 4, 1180-1182.

[35] Padilla, M., Aillapan, E., Navarro, P., et al. (2014) Effects of Manual Toothbrushing on Gingival Recession in an Adult Population Sample in South of Chile. International Journal of Odontostomatology, 8, 461-467. https://doi.org/10.4067/S0718-381X2014000300022

[36] Sambunjak, D., Nickerson, J.W., Poklepovic, T., Johnson, T.M., Imai, P., et al. (2011) Flossing for the Management of Periodontal Diseases and Dental Caries in Adults. Cochrane Database of Systematic Reviews, No. 12, CD008829. https://doi.org/10.1002/14651858.CD008829.pub2 
[37] Axelsson, P., Lindhe, J. and Nyström, B. (1991) On the Prevention of Caries and Periodontal Disease Results of a 15-Year Longitudinal Study in Adults. Journal of Clinical Periodontology, 18, 182-189.

https://doi.org/10.1111/j.1600-051X.1991.tb01131.x

[38] Chapple, I.L.C., Mealey, B.L., et al. (2018) Periodontal Health and Gingival Diseases and Conditions on an Intact and a Reduced Periodontium: Consensus Report of Workgroup 1 of the 2017 World Workshop on the Classification of Periodontal and Peri-Implant Diseases and Conditions. Journal of Clinical Periodontology, 45, S68-S77.

[39] Caton, J., Armitage, G., Berglundh, T., et al. (2018) A New Classification Scheme for Periodontal and Periimplant Diseases and Conditions-Introduction and Key Changes from the 1999 Classification. Journal of Clinical Periodontology, 45, S1-S8. https://doi.org/10.1111/jcpe.12935

[40] Papapanou, P.N., Sanz, M., et al. (2018) Periodontitis: Consensus Report of Workgroup 2 of the 2017 World Workshop on the Classification of Periodontal and Peri-Implant Diseases and Conditions. Journal of Clinical Periodontology, 45, S162-S170. 